tone to the "Principles" of his friend and fellow-labourer Lyell.

Two years after the "Considerations" appeared, Mr. Scrope published his great monograph on the volcanic districts of Central France-a work which placed him in a high rank as an accurate and philosophical observer, and one which did more, perhaps, than any other of its day, to destroy the Wernerian prejudice against volcanoes, and to establish the true volcanic origin of basalt rocks of every age. In another respect it marked an epoch in geological literature, inasmuch as it brought forward clear and detailed proofs of the gradual excavation of valleys by the action of the rivers still flowing in them-a doctrine taught indeed by Hutton, but for which there were still needed those very proofs which $\mathrm{Mr}$. Scrope's memoir so admirably supplied.

After this early promise of an active and brilliant scientific career, Mr. Scrope's energies passed over into another and wholly different mode of life. He entered Parliament, and continued an active member for some thirtyfour years. So thoroughly did he give himself up to political questions, that for fully a quarter of a century he seems to have retired from science altogether. About twenty years ago ( 1856 ), finding that the old notion of Humboldt and Von Buch about volcanic craters being merely big tumours or blisters pushed out by the expansion of the subterranean vapours, was still sufficiently in vogue to call forth an active opposition from Lyell, Mr. Scrope, who had long before exposed the untenability of this dogma, returned to his first love, and produced a paper upon "Craters and the Nature and Liquidity of Lavas." Other papers of a similar kind followed. In I 858 he brought out a second and revised edition of his memoir on the Auvergne volcanic region, and in 1862 he published a second-much altered and improved-edition of his general work on volcanoes. Since then he has communicated from time to time numerous brief letters and notices on his favourite subjects, showing how fully he retained his firm grasp of all that related to volcanic geology, and how young and fresh he could keep his powers.

This brief notice of his labours may fitly end with a tribute to that courtesy and kindliness which ever marked his relations with other men. A more leal-hearted friend could not be. How gladly would he say a kind word when a kind word would be of service! How ready, too, to help with more than words!

The founders of English geology have been truly a noble band - generous, helpful, and enthusiastic ; but few of them will be mure sincerely mourned than George Poulett Scrope.

A. G.

\section{SOMERSET HOUSE AND THE PUBLIC ANALYSTS}

$\mathrm{H}$ VER since the proposal was first made that disputed E. cases under the Sale of Food and Drugs Act should be referred to the analysts of the Board of Inland Revenue as adjudicators, there has been a strong feeling in the minds of most persons competent to form an opinion on the subject, that should such a course be ultimately adopted, the probable results would be great dissatisfaction on all sides. It was foreseen that the gentlemen most meritoriously engaged at Somerset House in testing the strength of alcoholic liquors, in examining the genuineness or otherwise of tobacco, tea, and excisable articles generally, and such like pursuits, would have great cause for complaint if work out of their ordinary department were thrust upon them, in the performance of which, even if no discredit should accrue to them by mistakes almost unavoidable in inexperienced hands, a considerable amount of professional odium would be probably incurred. It was clearly evident that the Public Analysts would be unjustly dealt with by the establishment of a system whereby the reports of men, frequentiy well known in the scientific world, and of great skill and experience in the special work requisite, would be liable to be superseded by those furnished by Government employés of far less professional and scientific standing, and specially qualified to a much lower extent. Finally, it was anticipated that a considerable injury to the public at large would be imminent, from the high probability that such an arrangement would lead to results not at all in harmony with the object of the Act. The checks on adulteration, it was feared, would be greatly diminished, partly through the bringing into more or less discredit the analysts appointed under the Act, and thus rendering their existence a far less effectual moral deterrent; and partly through the probable resignation of the higher class of analysts, and hence through the deprivation of the public of the special skill and experience acquired by these gentlemen.

That these dismal forebodings were not wholly groundless is shown by a recent case in the Southwark Police Court, the first, it may be mentioned, in which the Inland Revenue analysts have been appealed to under the new Act. On the I4th of last month, a large cheesemonger in the Borough appeared to answer a summons charging him with selling as butter a substance alleged to contain no butter, but to be a mixture of foreign fats not injurious to health. The proof of the purchase of the substance, and of the delivery of a sample to Dr. Muter, Public Analyst for the district, and the certificate of Dr. Muter to the above effect, were then given. The defendant demurring to the certificate, the case was adjourned in order that the third portion of the sample might be forwarded to Somerset House for examination by the Inland Revenue officers. On the I8th inst. the case came on for further hearing, and a certificate from Mr. Bell, of the Inland Revenue, was put in, stating that in his opinion the substance in question was genuine butter. This certificate was objected to by the presiding magistrate (Mr. Partridge) as being "extremely vague and unsatisfactory," inasmuch as it did not indicate that any analysis at all had been made, but only a cursory inspection. Mr. Bell thereupon gave an explanation of his certificate, stating that he had found the sample to contain water, 9.83; salt, 3.70; casein, 0.93; and fat, 85.54 per cent; that the fat yielded over 88 per cent. of fatty acids, and possessed the same specific gravity as butter fat, whence he concluded that there was no evidence of adulteration. In answer to questions, however, Mr. Bell admitted that although he had previously examined sundry specimens of genuine butter, and had seen some samples of "Bosh," he had ncver tested any specimen of the various artificial butters sold under the 
name of "Butterine." He also stated that his method of analysis was one unknown outside the Inland Revenue laboratory, and that the only test on which he placed much reliance was the specific gravity of the fatty matter, whilst he had been unable from the few experiments he had made to corroborate the statement of Messrs. Hehner and Angell, that genuine butter fat never yields more than about 86 per cent. of fatty acids on saponification.

Although the case could not be reopened, the evidence of several Public Analysts who had examined the sample was taken, and in most respects distinctly showed that the secret method of examination adopted by Mr. Bell was utterly unreliable. Dr. Dupré, F.R.S., Mr. Wigner, and Mr. de Konigh each found that the butter-fat contained close upon 94 per cent. of fatty acids, genuine butter not yielding more than 86 , and ordinary fats giving about 95 per cent. On microscopic examination a crystalline structure (evidence of fusion) was noticeable; the melting point was $4^{\circ} \mathrm{C}$. lower than genuine butter; the matter mistaken by Mr. Bell for caseine was no such substance, but only fragments of woody tissue and similar vegetable organised matter; the physical structure of the substance was different from that of genuine butter, as it possessed on the tongue the peculiar granular feeling of "butterine," and also tasted like the latter. The same results were also arrived at by other analysts, six having examined the sample, and all agreeing with Dr. Muter that the substance contained either no butter at all or very little.

On the other hand, Mr. Harkness and Mr. Lewes (assistant to $\mathrm{Mr}$. Bell) stated that they could see no crystals under the microscope, but admitted that woody fibre and other vegetable matter was present.

Finally, the case was dismissed, the Vestry being ordered to pay the costs of the Somerset House analysis; the magistrates, however, consented to grant a case for appeal if the Vestry desired to adopt that course.

Comment on the above would seem almost superfluous; but the question naturally arises, of what use is it in Government taking up valuable time in passing Acts, and in counties, districts, and parishes going to the expense of appointing analysts in accordance with these Acts, if the operations of these gentlemen are to be rendered nugatory by being liable to be overthrown by appeal to an authority which, however competent in reference to its own particular department, is nevertheless by its own showing scarcely possessed of sufficient experience, and is certainly not of sufficient standing and position to be admissible as a final adjudicator on such matters? The position of Public Analysts was surely bad enough without this indignity and injustice; most of the offices are grossly underpaid; the appointments are often in the hands of persons utterly incompetent to judge of the respective merits of candidates, and who not infrequently elect, not the applicant of highest scientific and professional standing, but the one who sinks his self-respect lowest by canvassing and flattering the electors. As a consequence many of the best known chemists refuse to have anything to do with such appointments, and the public loses the chance of valuable services. Further, when mistakes and blunders are made by persons who never ought to have been elected at all, there is a general cry against "the incompetence of Public Analysts," and discredit is brought on the whole class, worthy and unworthy alike. The inevitable results of insisting upon the analysts of Somerset House or any other set of men (unless specially trained and adapted for such a position) being made referees whose decisions shall override the results of careful and conscientious chemists, will be that the best and most accurate work of the Public Analysts will be wasted, that they themselves will be brought into contempt, that many of the best of them will be forced to resign their appointments, and finally, that the Act will become to a great extent a dead letter.

\section{HARTLEY'S "AIR AND ITS RELATION TO LIFE"}

Air and its Relation to Life. By Walter Noel Hartley, F.C.S., Demonstrator of Chemistry, and Lecturer on Chemistry in the Evening Class Department, King's College, London. (London: Longmans, Green, and Co., 1875.$)$

F all the so-called improvements which have been effected from time to time in the means by which we make ourselves comfortable and render ourselves independent of the limitations which nature would impose upon us-perhaps the introduction of gas was hailed and has been looked upon as among the greatest. It wants but little experience, however, of the manner in which people live in towns, to convince us that the reverse of this is the case, and that the pain and misery which it has been the means of inflicting must far outweigh its advantages. If anyone doubts this let him examine his sensations in a morning, after having spent the previous evening in a close room blazing with gas, and compare them with what he feels after having spent the corresponding hours in the open air, or in a fresh room moderately lighted with oil or candles. There are but few people to whom such experience would not show that the effect of the gas was a feeling of lassitude and depression, if not a downright headache; and if they were to repeat the experiment, who would not suffer a general loss of tone. Yet wherever gas is to be procured this is precisely the misery to which people subject themselves. In nine out of ten houses in the neighbourhood of towns, if one goes from the fresh air into a room in which the people are sitting on a winter evening, the first breath is enough to suffocate one, and yet the people within the room are entirely un. conscious; they may be more or less restless and depressed, but as this is their normal state they do not recognise the cause. In this way, to say nothing of what takes place in theatres and places of amusement, the evils which gas is answerable for are incalculable, though if they could be estimated they must far outweigh the blessings which accrue from the abundance and cheapness of its light.

The fact is that the money cost of the fuel forms only one part of the expense of light ; there is the consumption of oxygen, and in this gas is very extravagant; so that although we now obtain tenfold the light in our rooms which we had before the introduction of gas without any increase of expense in money, we have to pay for it by a tenfold vitiation of the air. Three or four gas flames consume as much air as a moderate fire, yet who would live in a room with a fire or even a pan of charcoal without a chimney. Yet it is a common thing to go into 